\title{
Aklimatisasi $\mathrm{pH}$ dan Pola Pertumbuhan Bacillus cereus S1 pada Medium MSM Modifikasi
}

\author{
A.N Fitria dan E. Zulaika \\ Departemen Biologi, Fakultas Ilmu Alam, Institut Teknologi Sepuluh Nopember (ITS) \\ e-mail: enny@bio.its.ac.id
}

\begin{abstract}
Abstrak-Pertumbuhan mikrooganisme dipengaruhi oleh sumber karbon, nitrogen, dan faktor lingkungan seperti suhu dan $\mathrm{pH}$. Karbon dan nitrogen digunakan oleh bakteri untuk membentuk material sel dan DNA. Setiap mikroorganisme memiliki pH optimal untuk pertumbuhannya. MSM (Mineral salt medium) merupakan medium minimal sumber karbon dengan komposisi garam - garam mineral esensial bagi mikroorganisme. MSM dapat digunakan sebagai medium yang potensial pada bidang bioremediasi dan bioakumulasi logam berat. Bacillus cereus $\mathrm{S} 1$ merupakan isolat bakteri yang diisolasi dari sedimen sungai Kali Mas Surabaya. Penelitian aklimatisasi pH dilakukan dengan empat kondisi pH berbeda yaitu pH 3; 4; 5 dan 6. Pola pertumbuhan pada medium MSM modifikasi dilakukan dengan 6 konsentrasi MSM yang berbeda. Pengukuran kepadatan sel menggunakan metode spektrofotometri UV-Vis dengan $\chi=600 \mathrm{~nm}$. Hasil penelitian menjukkan pH optimum bagi pertumbuhan $B$. cereus $S 1$ adalah pada pH 6. Hasil inkubasi 96 jam menunjukkan MSM modifikasi pada konsentrasi MSM;NB 1:3 memiliki pola pertumbuhan paling tinggi dibandingkan dengan konsentrasi lain. Kandungan pepton pada MSM;NB akan mempengaruhi akumulasi logam berat jika digunakan dalam penelitian bioremediasi. Sebagai alternatif lain MSM dengan penambahan Glukosa $2 \%$ memiliki pola pertumbuhan lebih baik dari $100 \%$ MSM dan hampir menyerupai pola pertumbuhan MSM;NB. MSM+Glukosa $2 \%$ dapat digunakan sebagai medium pertumbuhan dan akumulasi pada bidang bioremediasi.
\end{abstract}

Kata Kunci-Bacillus cereus S1, Glukosa, MSM, pH, Pertumbuhan.

\section{PENDAHULUAN}

$\mathrm{B}$ ACILLUS CEREUS S1 merupakan isolat bakteri berbentuk basil, Gram positif, katalase positif, aerob dan anaerob fakultatif, motif dan bersifat kemoorganotrof yang diisolasi dari sedimen sungai Kali Mas, Surabaya [1]. B. cereus memiliki mekanisme pembentukan endospora, dimana endospora memiliki resistensi tinggi terhadap cekaman temperatur tinggi dan bahan kimia [2]. struktur endospora meliputi eksosporium, mantel spora, korteks spora dan dinding inti. Endospora mengandung materi DNA, ribosom dan air yang dilindungi oleh dinding yang tersusun oleh asam dipikolinat [3].

Pertumbuhan dan perkembangan mikroorganisme dipengaruhi oleh faktor nutrisi dan faktor lingkungan. Nutrisi merupakan faktor penting bagi pertumbuhan mikroorganisme meliputi maktronutrient dan mikronutrien. Karbon (C), oksigen $(\mathrm{O})$, nitrogen $(\mathrm{N})$ dan hidrogen $(\mathrm{H})$ termasuk dalam komponen utama sebagai pembentuk material sel. Makronutrien lainnya meliputi fosfat (P), sulfur (S), kalium $(\mathrm{K})$, magnesium $(\mathrm{Mg})$, kalsium $(\mathrm{Ca})$ dan natrium $(\mathrm{Na})$. Mikronutrien meliputi besi (Fe) dan trace element metal $(\mathrm{Mn}$, $\mathrm{Co}, \mathrm{Ni}, \mathrm{Cu}$ dan $\mathrm{Zn}$ ) [3]. Selain nutrisi faktor lain yang mempengaruhi laju pertumbuhan dan aktivitas bakteri dipengaruhi oleh berbagai faktor, diantaranya yaitu $\mathrm{pH}$, suhu, tekanan osmosis, dan lain sebagainya. Akan tetapi, suhu dan pH merupakan faktor penting bagi pertumbuhan bakteri karena masing - masing spesies bakteri memiliki suhu dan $\mathrm{pH}$ optimum untuk pertumbuhannya [4]. $\mathrm{pH}$ optimal untuk pertumbuhan bakteri dibagi menjadi tiga tipe yaitu acidhopile, neuthropile dan alkalophile [5]. Acidhopile, yaitu tumbuh optimum pada rentang $\mathrm{pH} 0$ sampai 5, Neutrophile, tumbuh optimum pada rentang $\mathrm{pH} 5,5$ sampai 8,0, dan Alkalophile, tumbuh optimum pada rentang $\mathrm{pH}$ 8,5 sampai 11,5 .

MSM merupakan medium minimal sumber karbon. Komposisi MSM terdiri dari garam - garam mineral yang esensial bagi mikroorganisme. Garam mineral pada MSM termasuk kedalam mikronutrien yang dibutuhkan mikroorganisme dalam jumlah kecil. MSM digunakan pada bidang bioremediasi karena tidak adanya sumber karbon sehingga memaksa bakteri memanfaatkan sumber karbon lain yang sengaja ditambahkan pada medium [6]. Tujuan dari penelitian ini adalah untuk mengetahui $\mathrm{pH}$ optimum bagi pertumbuhan B. cereus S1 dan mengetahui pola pertumbuhan isolat pada MSM yang dimodifikasi.

\section{METODOLOGI PENELITIAN}

\section{A. Peremajaan Isolat dan Pembuatan Starter}

Isolat B. cereus $\mathrm{S} 1$ didapat dari koleksi Laboratorium Mikrobiologi dan Bioteknologi Departemen Biologi ITS. Isolat disubkulturkan pada medium Nutrient Agar (NA) dengan metode gores sinambung. Isolat diinkubasi selama 24 jam dalam inkubator dengan suhu $37^{\circ} \mathrm{C}$. Pembuatan starter dilakukan secara bertingkat diawali dengan inokulasi 3 ose isolat kedalam Nutrient Broth (NB) $10 \mathrm{ml}$, diinkubasi selama 12 jam selanjutnya ditumbuhkan pada medium Nutrient broth (NB) $90 \mathrm{ml}$ dan diinkubasi selama 12 jam sebagai kultur starter.

\section{B. Aklimatisasi Isolat terhadap $\mathrm{pH}$}

Medium untuk aklimatisasi $\mathrm{pH}$ dibuat dengan menambahkan $\mathrm{NaOH} 1 \mathrm{M}$ dan $\mathrm{HCl} 1 \mathrm{M}$ pada NB hingga mencapai 3; 4; 5 dan 6. Kultur starter dengan OD 0,6 - 0,8 diinokulasikan secara aseptis ke dalam medium masing masing sebanyak $5 \mathrm{ml}$, volume total inokulum $50 \mathrm{ml}$. Inkubasi dilakukan pada suhu ruang selama 12 jam. Kepadatan sel diukur optical density (OD) dengan spektrofotometer UV-Vis $(\chi=600 \mathrm{~nm})$. Berdasarkan data OD dibuat pola pertumbuhan B. cereus $\mathrm{S} 1$. 


\section{Aklimatisasi Isolat Terhadap Mineral Salt Medium (MSM)}

MSM dibuat dengan komposisi (g/L) $\mathrm{MgSO}_{4}$ 0,2 gram, $\mathrm{CaCl}_{2}$ 0,02 gram, $\mathrm{KH}_{2} \mathrm{PO}_{4} 1$ gram, $\mathrm{K}_{2} \mathrm{HPO}_{4} 1$ gram, $\mathrm{NH}_{4} \mathrm{NO}_{3}$ 1 gram, $\mathrm{FeCl}_{2}$ 0,05 gram. MSM untuk aklimatisasi dibuat dengan konsentrasi NB : MSM dengan perbandingan 1;3, 1;1, 3;1 dan 5:95, MSM + Glukosa 2\% serta 100\% MSM. Volume akhir masing - masing konsentrasi adalah $100 \mathrm{~mL}$. Aklimatisasi dilakukan dengan cara menginokulasi kultur starter sebanyak $10 \mathrm{ml}$ ke dalam $90 \mathrm{ml}$ medium NB dan MSM yang telah disesuaikan konsentrasinya. Volume akhir medium adalah $100 \mathrm{ml}$ dengan $\mathrm{pH}$ 6. Kultur diinkubasi selama 96 jam pada rotary shaker dengan kecepatan $100 \mathrm{rpm}$. Kepadatan sel diukur optical density (OD) dengan spektrofotometer UV-Vis $(\chi=600 \mathrm{~nm})$. Berdasarkan data OD dibuat pola pertumbuhan $B$. cereus $\mathrm{S} 1$.

\section{HASIL DAN DISKUSI}

\section{A. Viabilitas B. cereus S1 pada aklimatisasi pH}

Uji viabilitas dilakukan untuk mengetahui $\mathrm{pH}$ optimal bagi pertumbuhan $B$ cereus S1. B. cereus S1 memiliki pola pertumbuhan yang baik pada $\mathrm{pH} 5$ dan $\mathrm{pH}$ 6. Pola pertumbuhan pada $\mathrm{pH} 3$ dan 4 cenderung stagnan (Gambar 1). B.cereus $\mathrm{S} 1$ memiliki $\mathrm{pH}$ optimum untuk pertumbuhan antara $\mathrm{pH} 6$ - 8, sedangkan $\mathrm{pH}$ minimumnya pada $\mathrm{pH}$ 4,3 [4].

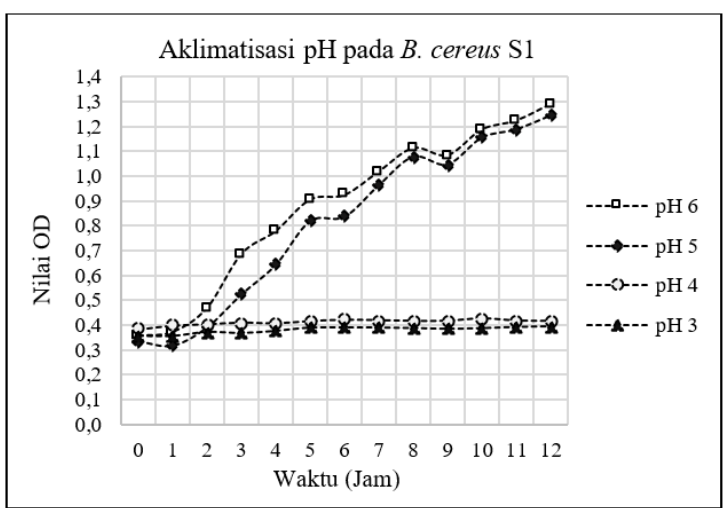

Gambar 1. Pola pertumbuhan B. cereus $\mathrm{S} 1$ pada medium NB dengan $\mathrm{pH} 3$; 4; 5 dan 6 .

Pertumbuhan $B$. cereus S1 pada pH 6 menunjukkan pola pertumbuhan yang lebih tinggi dibandingkan dengan $\mathrm{pH} 5 ; 4$ dan 3 yang lebih asam. Hal ini disebabkan oleh kemampuan isolat melakukan mekanisme homeostatis $\mathrm{pH}$. Tingkat keasaman pH 6 mendekati dari $\mathrm{pH} 7$, dimana $\mathrm{pH} 7$ merupakan keadaan netral [3]. Sitoplasma memiliki $\mathrm{pH}$ antara 7,4 hingga 7,8 [7]. Bakteri memiliki mekanisme homeostatis $\mathrm{pH}$ karena adanya membran untuk transport anion dan kation pada kondisi tercekam pH [3]. Pada kondisi pH lebih asam, maka konsentrasi $\mathrm{H}^{+}$diluar sel akan lebih banyak dari sel. Hal ini dapat menyebabkan difusi $\mathrm{H}^{+}$dari medium kedalam sel. Akumulasi $\mathrm{H}^{+}$berlebih diperiplasma menyebabkan porin tersumbat, proton motif force terhambat, dan permeabilitas membran terganggu [7]. Pertumbuhan isolat pada $\mathrm{pH} 6$ menunjukkan pola pertumbuhan yang lebih baik dibandingkan dengan $\mathrm{pH}$ lainnya karena medium memiliki perbedaan $\mathrm{pH}$ yang lebih kecil dengan $\mathrm{pH}$ sitoplasma. Hal ini menunjukkan homeostatis $\mathrm{pH}$ antara intraseluler dan ekstraseluler berjalan dengan baik.

Pertumbuhan isolat pada $\mathrm{pH} 3$ dan 4 sangat rendah jika di bandingkan dengan pH 5 dan 6 . Hal ini dapat terjadi karena bakteri melakukan stategi bertahan hidup tanpa pembelahan dan resistensi endospora terhadap $\mathrm{pH}$ asam menurun [7]. Endospora bakteri dapat mengalami kerusakan pada cekaman asam tinggi. Pada kondisi asam endospora Bacillus cereus akan melepas asam dipikolinat secara berkala sehingga permeabilitas dari endospora menurun [8]. Paparan kondisi yang sangat asam dapat mengakibatkan kerusakan membran dan lepasnya komponen intraseluler [9]. Hilangnya komponen-komponen intraseluler seperti magnesium $(\mathrm{Mg})$, kalium (K) dan lemak dari sel dapat menyebabkan kematian sel. B. cereus $\mathrm{S} 1$ tumbuh dengan baik di $\mathrm{pH} 6$.

\section{B. Pola Pertumbuhan B. cereus S1 pada Medium Modifikasi MSM}

Mineral Salt Medium (MSM) merupakan medium pertumbuhan bakteri dimana didalamnya hanya terdapat garam-garam mineral yang esensial bagi organisme. Pada penelitian sebelumnya MSM digunakan pada bidang bioremediasi [6]. Komposisi MSM yang tidak mengandung sumber karbon diharapkan akan mendorong mikroorganisme untuk memanfaatkan sumber karbon lain yang sengaja ditambahkan. Aklimatisasi MSM dilakukan dengan inkubasi selama 96 jam dengan konsentrasi MSM : NB yang berbeda, kondisi $\mathrm{pH}$ sama yaitu pada $\mathrm{pH}$ 6. Hasil aklimatisasi berupa pola pertumbuhan selama aklimatisasi 96 jam dapat dilihat pada gambar 2 .

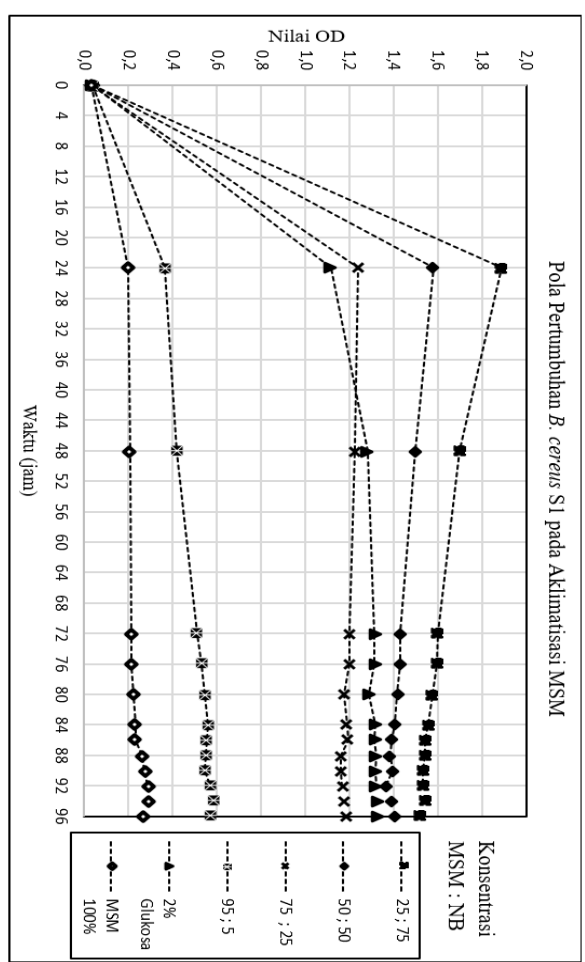

Gambar 2. Pola Pertumbuhan B. cereus S1 Hasil Aklimatisasi Modifikasi Medium MSM, NB dan Glukosa pada $\mathrm{pH} 6$

MSM dapat digunakan dalam penelitian biomineralisasi, bioakumulasi dan bioremediasi logam berat. Komposisi MSM tidak mengandung protein dan glukosa sehingga tidak membentuk ligand dengan logam berat [10]. Pola pertumbuhan isolat pada medium 100\% MSM dan 95\% MSM menunjukkan pola pertumbuhan yang stagnan. Pertumbuhan isolat hingga 96 jam inkubasi sangat kecil dengan OD berkisar antara 0,03 sampai 0,27. Hal ini 
disebabkan oleh tidak adanya sumber karbon pada medium. Karbon (C) digunakan oleh sel sebagai penyusun material sel, kekurangan sumber karbon menyebabkan terhambatnya pembentukan material sel dan mempengaruhi pertumbuhan bakteri [11].

Medium dengan perbandingan MSM dan NB $1: 3$ memiliki pola pertumbuhan lebih baik dari $100 \%$ MSM dan 95\% MSM. Hal ini disebabkan oleh adanya kandungan pepton dan ekstrak daging pada NB sebagai sumber karbon bagi pertumbuhan isolat [12]. Medium yang memiliki kandungan pepton dapat mempengaruhi akumulasi logam berat oleh sel bakteri. Peptone memiliki gugus fungsi hidroksil, sulfihidril, asam karboksilat, karboksamida, amina dan karboksil [13]. Gugus fungsi amina dan karboksil pada peptone akan berikatan dengan logam berat pada medium, sehingga akumulasi oleh bakteri tidak berjalan optimal [14].

Sebagai pengganti pepton, glukosa dapat digunakan sebagai sumber karbon pada medium pertumbuhan [11]. Gugus fungsi glukosa berupa hidroksil dan aldehid. Kedua gugus tersebut akan sulit membentuk ligand dengan logam berat termasuk $\mathrm{Au}(\mathrm{III})$ karena kecenderungan $\mathrm{Au}(\mathrm{III})$ akan berikatan dengan nitrogen (N) dan sulfur (S) [14]. Pola pertumbuhan isolat pada MSM+Glukosa $2 \%$ menunjukkan hasil yang lebih baik dibandingkan dengan pertumbuhan pada $100 \%$ MSM dan hampir menyerupai pola pertumbuhan pada NB.

\section{KESIMPULAN}

Berdasarkan penelitian yang telah dilakukan, dapat disimpulkan bahwa:

1) B. cereus $\mathrm{S} 1$ menunjukkan pertumbuhan yang optimal pada $\mathrm{pH} 6$.

2) Medium pertumbuhan MSM dengan penambahan Glukosa $2 \%$ merupakan medium pertumbuhan yang dapat digunakan dalam penelitian bioakumulasi dan bioremediasi logam berat.

\section{DAFTAR PUSTAKA}

L. S. and A. S. Zulaika E., "Characterization and dentification of Mercuryresistant Bacteria from Kalimas River SurabayaIndonesia by Numerical Phenetic Taxonomy," J. Bacis Appl. Sci. Res., vol. 2, no. 7, pp. 7263 - 7269, 2012.

[2] M. M. and A. T, "Bacillus cereus responses to acid stress," Environ. Microbiol., vol. 13, no. 11, pp. 2835 - 2843, 2011.

[3] D. A. S. and D. . C. Madigan M.T., J.M., Martinko, Brock. Biology of Microorganism Thirteenth Edition. San Francisco: Benjamin Cummings, 2011.

[4] E. F. S. A. (EFSA), "Opinion of the Scientific Panel on Biological Hazards on Bacillus cereus and other Bacillus spp in foodstuff,' EFSA J., vol. 175, pp. 1-48, 2005.

[5] and W. C. J. Willey J.M., Sherwood L.M., Prescott, Harley, and Klein's Microbiology Seventh Edition. New York: The McGrawHill Companies, Inc, 2008.

[6] R. S. and A. P. . Prabharkaran P., Sureshbabu A., "Bioremediation of Crude Oil in Synthetic Mineral Salts Medium Enriched With Aerobic Bacterial Consortium," Int. J. Innov. Res. Sci. Eng. Technol., vol. 3, no. 2, 2014.

[7] and P. E. Krulwich T.A., Sachs G., "Molecular aspect of bacterial pH sensing and homeostasis," Nat Rev Microbiol, vol. 9, no. 5, pp 330 - 343, 2011

[8] S. C. A. S. P. Setlow B., Loshon C.A., Genest P.C., Cowan A.E. "Mechanisms of killing spores of Bacillus subtilis by acid, alkali and ethanol," J. Appl. Microbiol., vol. 92, pp. 362-375, 2002.

[9] C. L. A. leguerinel I. Desriac N., Broussolle V., Postollec F., Mathot A.G., Sohier D., "Bacillus cereus cell response upon exposure to acid environment: toward the identification of potential biomarkers," Front. Microbiol., vol. 4, p. 284, 2013.

[10] and D. B. Zhou J.C., Wang X., Xue M., Xu Z., Hamasaki T., Yang Y., Wang K., "Characterization of gold nanoparticle binding to microtubule filaments," Mater. Sci. Eng., vol. C 30, pp. 20-26, 2010

[11] A. S, Prinsip Dasar Ilmu Gizi, 6th ed. Jakarta: Gramedia Pustaka Utama, 2006

[12] U. S. F. and D. Administration, "Bacteriological analytical manual, online," AOAC Int., 2001.

[13] S. L. Berg JM, Tymoczko JL, "Protein Structure and Function," in Biochemistry, 5th ed., New York: W H Freeman, 2002.

[14] et al Reith F., Etschmann B., Grosse C., Moors H., Benotmane M.A., Monsieurs P., "Mechanisms of gold biomineralization in the bacterium Cupriavidus metallidurans," PNAS, vol. 106, no. 42, pp $17757-17762,2009$ 